\title{
Cellular and Humoral Components of Monocyte and Neutrophil Chemotaxis in Cord Blood
}

\author{
SAVITA G. PAHWA, ${ }^{(35)}$ RAJENDRA PAHWA, ELENA GRIMES, AND ELIZABETH SMITHWICK \\ Department of Pediatrics and Immunology, Memorial Sloan-Kettering Cancer Center, New York, New York, USA
}

\begin{abstract}
Summary
Monocyte and polymorphonuclear neutrophil (PMN) chemotaxis was studied in cord blood from healthy term infants. Monocyte chemotaxis was normal to increased (115-126\%) whereas PNIN chemotaxis was decreased $(79 \%)$ in comparison with that of healthy adult control subjects. Generation of chemotactic factors from cord sera was impaired, being $55 \%$ of that generated by pooled normal human serum (PNHS). Cord serum was less inhibitory than pooled adult human serum for adult monocytes when the cells were suspended in $10 \%$ serum and tested for chemotaxis. No inhibition of chemotactic factors by either cord or adult sera was observed. The dissociation of chemotactic response of the two different phagocytic cells may represent a protective mechanism whereby one cell can compensate for a defect in the response of the other.
\end{abstract}

\section{Speculation}

Simultaneous analysis of monocyte and neutrophil chemotaxis may reveal a defect restricted to one cell type.

The human newborn infant is uniquely susceptible to infection with a variety of infectious agents (bacterial, viral, fungal, and protozoal) which often results in disseminated disease. Many studies of the defense mechanisms in newborn infants have been done, including studies of cell-mediated and humoral immunity $(12,18)$, neutrophil function $(9,20,23)$, inflammatory response $(8,10)$, and the complement system $(2,17)$. Little information is available about the monocyte, a cell of great importance in both the afferent and efferent limb of the immune response. Evidence in mice (1), rats (3), and rabbits (24) suggests that the neonate has a deficiency in macrophage function. In humans, evaluation of the newborn infant's inflammatory response using the Rebuck skin window showed a delayed and diminished accumulation of monocytes (8), suggesting a possible defect in monocyte migration. Two recent studies on monocyte chemotaxis give conflicting results. One, done in 1- to 5-day-old infants, reports decreased chemotaxis (15) and the other, done in cord blood, reports normal chemotaxis (16).

The investigations reported here were designed to evaluate the cellular and humoral components of monocyte chemotaxis in the newborn infant, using cord blood. Previously, Miller (21) had reported an impairment of neutrophil chemotaxis and in the generation of serum chemotactic factors in 3- to 5-day-old infants. The present study was expanded to include neutrophil chemotaxis $(I)$ to see whether the defects described in newborn infants were also present in cord blood, and (2) to see whether the responses of monocytes and neutrophils resembled each other.

\section{MATERIALS AND METHODS}

Heparinized (20 units/ml) cord blood, obtained from healthy full term infants, was tested within $4 \mathrm{hr}$ of delivery. In every experiment, blood from a healthy adult was tested simultaneously.

\section{ISOLATION OF CELLS}

Mononuclear leukocytes were isolated by density gradient centrifugation on a sodium metrizoate-Ficoll solution (Lymphoprep, Nyegard and Co., Oslo) (5). The cells were washed three times and resuspended in RPMI (Gibeo) supplemented with penicillin 50 units, streptomycin $50 \mu \mathrm{g}$, and glutamine $2 \mathrm{mM} / \mathrm{ml}$. As simultaneous analysis of monocytes by myeloperoxidase stain and Wright stain were in close agreement, the pereentage of monocytes was routinely determined by a myeloperoxidase stain (13); Wright stain was done to exclude contamination by granulocytes. The final cell concentration was adjusted to $1.5 \times 10^{6}$ monocytes/ml.

To isolate polymorphonuclear neutrophils, the granulocyterich, red blood cell sediment from the Lymphoprep gradient was resuspended in RPMI 1640; the red blood cells were then sedimented with 6\% dextran in saline solution (Abbott). Red blood cells remaining in the leukocyte-rich supernatant were lysed with hypotonic saline. The leukocytes were then washed three times and resuspended in minimum essential medium $\left(\right.$ MEM, Gibco) at a concentration of $1.0 \times 10^{6} \mathrm{PMN} \mathrm{s} / \mathrm{ml}$.

\section{CHEMOTACTIC STIMULI}

Lymphocyte-derived Chemotactic Factor (LDCF). This lymphokine was prepared by concanavalin $\mathrm{A}(10 \mu \mathrm{g} / \mathrm{ml})$ stimulation of lymphocytes. Cultures containing $2 \times 10^{15} \mathrm{lymphocytes} / \mathrm{ml}$ in RPMI 1640 without serum were incubated at $37^{\circ}$ in $5 \% \mathrm{CO}_{2^{-}}$ $95 \%$ humidified air for $48 \mathrm{hr}$. After centrifugation, the supernatant fluid was stored in aliquots at $-70^{\circ}$ until used. LDCF was used as the chemotactic stimulus for monocytes in the following proportion: $30 \%$ LDCF, 40\% RPMI 1640, and 30\% Hank's balanced salt solution with $\mathrm{Ca}^{++}, \mathrm{Mg}^{++}$, and $1 \%$ gelatin (HBSS$\mathrm{G)}$.

Activated serum (AS). Pooled normal human serum (PNHS) was stored in aliquots at $-70^{\circ}$ and thawed just before use. The serum was activated with endotoxin (Escherichia coli 026:B6, Difco), $300 \mu \mathrm{g} / \mathrm{ml}$ at $37^{\circ}$ for $60 \mathrm{~min}$, followed by inactivation at $56^{\circ}$ for $30 \mathrm{~min}$. The proportions used were serum $0.1 \mathrm{ml}$, endotoxin $0.1 \mathrm{ml}$, HBSS-G $1.0 \mathrm{ml}$, and MEM $0.8 \mathrm{ml}$, which gave a final serum concentration of $5 \%$. This stimulus was tested against both monocytes and PMN's.

Appropriate controls, without any chemotactic stimuli, were tested simultaneously. These consisted of $40 \%$ medium (RPMI for monocytes and MEM for PMN's) and 60\% HBSS-G.

\section{CHEMOTAXIS ASSAY}

The test procedure was a modification of the method of Snyderman et al. (26). All assays were done in triplicate.

Modified Boyden chemotactic chambers (Blind-IVell, Neuroprobe) were used. The wells of the chambers were filled with 0.2 $\mathrm{ml}$ of the chemotactic stimulus, delivered with a calibrated pi- 
pette (Finnpipette, Neuroprobe). Numbered filters (Nuclepore) of pore size $5 \mu \mathrm{m}$ for monocytes and $3 \mu \mathrm{m}$ for PMN's were placed over the filled wells, taking care not to trap bubbles. The filter retainers were then serewed in, and the upper compartments charged with $0.2 \mathrm{ml}$ of the appropriate cell suspension. The chambers were incubated at $37^{\circ}$ in humidified air for a period of 90 min for monocytes and 45 min for PMN's. After incubation, the upper compartments were aspirated and the filters were removed and stained in Mayer's hematoxylin. Cells migrating to the undersurface of the filter were counted, using an ocular grid $(7 \times 7 \mathrm{~mm})$, with a magnification of 1,000 times for monocytes and 400 times for PMN's. Ten random grid fields were counted on every filter. The results were expressed as the mean number of cells per ocular grid and as a percentage of the normal.

\section{STUDY OF SERUM FACTORS}

Using the basic techniques described above, experiments were done to evaluate the following.

Ability to Generate Chemotactic Factor. Cord sera and PNHS were tested simultaneously for chemotactic activity after endotoxin activation, using adult PMN's as test cells.

Inhibitors of Cells. Normal monocytes and PMN's were suspened in either $10 \%$ cord serum or $10 \%$ PNHS; $10 \%$ activated normal serum was used as the chemotactic stimulus.

Inhibitors/Inactivators of Chemotactic Stimuli. Cord serum or normal serum, $5 \%$, was added to $5 \%$ activated normal serum. This $10 \%$ serum mixture was used as the chemotactic stimulus for normal PMN's. Similarly, cord or normal serum, 10\%, was added to the $30 \%$ LDCF and tested against normal monocytes.

\section{RESULTS}

\section{MONOCYTE CHEMOTAXIS}

The percentage of monocytes in cord mononuclear cells was consistently higher than that in adult cells: $25 \pm 8 \%$ versus $16 \pm$ $5 \%$, respectively. The final monocyte concentrations were adjusted as described above such that the chambers all received equal numbers of either cord or adult monocytes. LDCF was the chemotactic stimulus for 24 cord samples; AS was used as an additional stimulus in 12 (Table 1). Of those tested with LDCF, 12 had an increased response, ranging from $122-158 \%$ of the adult values, whereas the other 12 had a normal response (85$115 \%)$. The mean response of the cord monocytes was significantly higher $(126 \%)$ than the adult response $(P<0.0025)$. The mean response was also higher for AS (115\%), but not significantly so. The mean background count (control chambers) for cord monocytes was also significantly higher $(P<0.005)$.

\section{PMN CHEMOTAXIS}

Eleven cord samples were tested for PMN response to chemotactic influence using activated serum as the stimulus. Of these,

Table 1. Response of cord and adult monocytes to chemotactic stimuli

\begin{tabular}{|c|c|c|c|c|}
\hline \multirow[b]{2}{*}{$\begin{array}{l}\text { Stimu- } \\
\text { lus }\end{array}$} & \multicolumn{2}{|c|}{ Mean chemotactic response' } & \multirow{2}{*}{$\begin{array}{c}\text { Cord/ } \\
\text { adult, } \\
\%\end{array}$} & \multirow[b]{2}{*}{$P$ value } \\
\hline & Cord monocytes & $\begin{array}{l}\text { Adult mono- } \\
\text { cytes }\end{array}$ & & \\
\hline $\mathrm{LDCF}^{2}$ & $28.9 \pm 5.6(n=24)$ & $22.9 \pm 5.9$ & 126 & $<0.0025$ \\
\hline $\mathrm{AS}^{3}$ & $33.1 \pm 7.0(n=12)$ & $28.7 \pm 6.1$ & 115 & $>0.5$ \\
\hline Control $^{4}$ & $6.0 \pm 3.5$ & $3.5 \pm 2.2$ & 171 & $<0.005$ \\
\hline
\end{tabular}

' Mean cells \pm 1 SD/grid at a magnification of 1,000 times. $n$ indicates the number of cord samples tested.

2 Lymphocyte-derived chemotactic factor.

${ }^{3}$ Endotoxin-activated normal serum.

"No chemotactic stimulus. HBSS-G (see "Materials and Methods") $60 \%$; RPMI $40 \%$. eight showed a decreased response and three had a response equal to that of adult PMN's (Table 2). The mean chemotactic response of cord PMN's was $79 \%$ of that of adults $(P<0.05)$ Background counts of cord and adult PMN's were similar.

\section{GENERATION OF SERUM CHEMOTACTIC FACTOR}

Cord sera generated less chemotactic activity for PMN's than did PNHS. The chemotactic response of adult PMN's to activated cord sera was $55 \%$ of that seen with activated PNHS, $P<$ 0.0005 (Table 3).

\section{SERUM INHIBITORS OF CHEMOTAXIS}

Adult mononuclear cells suspended in serum showed a lower monocyte chemotactic response than that of cells suspended in medium alone. PNHS was more inhibitory than cord serum, there being $51 \%$ inhibition of monocyte chemotaxis by PNHS, and $26 \%$ inhibition by cord serum (Table 4 ). Monocytes in cord serum showed a consistently higher response to $10 \%$ AS than when suspended in PNHS $(P<0.05)$. On the other hand, the response of PMN's suspended in cord serum varied from a slightly decreased to a slightly increased response as compared with cells suspended in PNHS, but no significant differences were observed. Only minimal inhibition by either serum was seen. Cord cells similarly suspended in either PNHS or cord serum were not tested.

\section{SERUM INHIBITORS/INACTIVATORS OF CHEMOTACTIC FACTORS}

There was no evidence of any inhibitor or inactivator in unfractionated cord or pooled normal serum to either of the chemotactic factors tested. Monocytes exhibited an increased response to LDCF which had added cord or pooled normal human serum than when exposed to LDCF alone (Table 5). Addition of either $5 \%$ cord or pooled adult serum to $5 \%$

Table 2. Response of cord and adult polymorphomuclear neutrophils (PMN's) to endotoxin-activated normal serum (AS)

\begin{tabular}{|c|c|c|c|c|}
\hline \multirow[b]{2}{*}{$\begin{array}{l}\text { Stimu- } \\
\text { lus }\end{array}$} & \multicolumn{2}{|c|}{ Mean chemotactic response' } & \multirow{2}{*}{$\begin{array}{c}\text { Cord/ } \\
\text { adult, } \\
\%\end{array}$} & \multirow[b]{2}{*}{$P$ value } \\
\hline & Cord PMN's & $\begin{array}{l}\text { Adult } \\
\text { PMN`s }\end{array}$ & & \\
\hline AS & $69.9 \pm 22.4(n=11)$ & $88.2 \pm 15.2$ & 79 & $<0.05$ \\
\hline Control $^{2}$ & $24.2 \pm 6.0$ & $21.0 \pm 8.5$ & 114 & N.S. \\
\hline
\end{tabular}

1 Mean cells $\pm 1 \mathrm{SD} / \mathrm{grid}$ at a magnification of 400 times. $n$ indicates number of cord samples studied.

${ }^{2}$ No chemotactic stimulus. HBSS-G (see "Materials and Methods") $60 \%$; minimum essential medium $40 \%$.

Table 3. Serum chemotactic activity for normal adult polymorphonuclear neutrophils (PMN's)

\begin{tabular}{lc}
\multicolumn{1}{c}{ Stimulus } & $\begin{array}{c}\text { Mean chemotactic re- } \\
\text { sponse, } 1 \text { PMN's }\end{array}$ \\
\hline $5 \%$ Cord serum $(n=7)^{2}$ & \\
Activated & $41.5 \pm 12.2$ \\
Not activated & $18.3 \pm 5.2$ \\
$5 \%$ Pooled normal human serum & $75.1 \pm 11.3$ \\
Activated & $17.8 \pm 5.6$ \\
Not activated $^{2}$ & $21 \pm 5.2$ \\
Control & \\
\% Response to activated cord serum &
\end{tabular}

${ }^{1}$ Mean cells $\pm 1 \mathrm{SD} / \mathrm{grid}$ at a magnification of 400 times.

${ }^{2} n$ indicates number of cord samples tested.

${ }^{3}$ No chemotactic stimulus. HBSS-G (see "Materials and Methods") $60 \%$; minimum essential medium, $40 \%$.

${ }^{4}$ Mean response to activated cord serum/Mean response to activated pooled normal human serum $\times 100$. 
Table 4. Effects of cord serum and normal serum on chemotactic response of normal cells ${ }^{1}$

\begin{tabular}{lcc}
\hline Cell suspension & Chemotactic responsez & $\begin{array}{c}\text { Inhibition, } \\
\%\end{array}$ \\
\hline Monocytes & & \\
In $10 \%$ cord serum & $22.3 \pm 5.46$ & 26 \\
In 10\% PNHS & $14.6 \pm 5.67$ & 51 \\
In medium alone & $30.1 \pm 3.79$ & \\
PMN's & & \\
In 10\% cord serum & $73.1 \pm 10.4$ & 12 \\
In $10 \%$ PNHS & $69.8 \pm 13.5$ & \\
In medium alone & $79.6 \pm 15.6$ & \\
\hline
\end{tabular}

1 These data represent the mean of four experiments in which $17 \mathrm{cord}$ sera were tested. PNHS: pooled normal human serum.

${ }^{2}$ Mean cells per grid at a magnification of 1,000 times for monocytes and 400 times for polymorphonuclear neutrophils. Stimulus: $10 \%$ activated $\mathrm{PNHS}$.

Table 5. Effect of cord and adult serum on chemotactic factors ${ }^{1}$

\begin{tabular}{lr}
\multicolumn{1}{c}{ Stimulus } & $\begin{array}{c}\text { Chemotactic re- } \\
\text { sponse }\end{array}$ \\
\hline $\begin{array}{l}\text { Monocytes } \\
30 \% \text { LDCF }\end{array}$ & $22.4 \pm 5.9$ \\
$30 \%$ LDCF + $10 \%$ cord serum $(n=5)^{3}$ & $26.1 \pm 2.5$ \\
$30 \%$ LDCF + $10 \%$ PNHS & $26.6 \pm 3.6$ \\
Control & $3.3 \pm 1.8$ \\
PMN's & \\
$5 \%$ AS & $89.6 \pm 11.3$ \\
$5 \%$ AS $+5 \%$ cord serum $(n=9)$ & $88.1 \pm 11.3$ \\
$5 \% \mathrm{AS}+5 \%$ PNHS & $90.1 \pm 13.1$ \\
Control & $22.8 \pm 6.2$ \\
\hline
\end{tabular}

${ }^{1}$ LDCF: lymphocyte-derived chemotactic factor; PNHS: pooled normal human serum; AS: activated serum.

${ }^{2}$ Mean cells per grid at a magnification of 1,000 times for monocytes and 400 times for polymorphonuclear neutrophils.

${ }^{3} n$ indicates number of cord sera tested.

"No chemotactic stimulus. HBSS-G (see "Materials and Methods") $60 \%$; RPMI or minimum essential medium, $40 \%$.

activated serum did not influence the PMN chemotactic response.

\section{DISCUSSION}

A major aim of this study was to investigate one aspect of monocyte function, chemotaxis, using cord blood cells to see whether an inability to migrate contributed to the disseminated infections and slower immune responses which are characteristic of the newborn infant. It has been suggested that the neonate has competent lymphoid cells but lacks functional macrophages (1, 6).

Contrary to our expectations, the cord monocyte chemotactic response to two different stimuli, endotoxin-activated normąl serum (AS) and lymphocyte-derived chemotactic factor (LDCF), was normal to increased when compared with adult monocytes. Simultancous studies of neutrophil (PMN) chemotaxis revealed a decreased response, confirming an earlier report by Miller of a deficiency of the PMN chemotactic response of the human neonate (21). A dissociation of chemotactic function between the two major phagocytic cells has not been reported previously. This dichotomy in the response of monocytes and neutrophils may represent a protective mechanism whereby an increased response of one cell type can compensate for the decreased response of the other.

Random mobility of cord monocytes as assayed by migration through a micropore filter was also increased, whereas cord PMN's did not differ from normal adult PMN's. Discrepancies between neutrophil migration as measured in vivo by the
Rebuck window and in vitro by the Boyden chamber have been described (22). A similar variance seems to exist for newborn monocyte migration: namely, increased movement in vitro but decreased and delayed monocyte accumulation in vivo. The increased mobility of cord monocytes as compared to monocytes from healthy adults suggests that these cells are activated in their resting state in the neonatal period. Such a state could result from some as yet undefined maternal stimulus, or be secondary to the stress of delivery. In this regard it might be of interest to compare spontaneous mobility of maternal and cord blood monocytes.

$E$. coli endotoxin activates the complement system mainly by the alternate pathway, and also by the classic pathway utilizing antibody. It has been previously demonstrated that when the classic pathway is blocked, chemotactic factor generated by endotoxin is kinetically slower, but reaches normal levels if activation is carried out for 60 min (11). Low levels of natural antibody to endotoxin in cord serum would prevent activation of the classic complement pathway, but it would still be possible to activate the alternate pathway and generate normal amounts of chemotactic factor if the necessary complement components were present. In our experiments, activation of serum with endotoxin was carried out for $1 \mathrm{hr}$, resulting in decreased chemotactic activity in cord serum. Here, although one cannot rule out a deficiency of endotoxin antibody, there seems little doubt of associated complement deficiencies. Cord serum is known to be deficient in all components of the complement system (2). A similar deficiency of neonatal serum in the generation of chemotactic factor for PMN's has been previously described where bacteria and antigen-antibody complexes were used to generate chemotactic activity (21). Besides hypocomplementemia, another mechanism for abnormal serum chemotactic activity is the inhibition or inactivation of chemotactic factor by other serum factors. An inactivator of chemotactic factors for monocytes and PMN's is present in normal human serum (4), but this activity is not expressed in unfractionated serum. If there is an increased amount of a chemotactic factor inactivator, as happens in certain disease conditions such as Hodgkin`s disease (31) and cirrhosis (19), it is active in unfractionated serum as well. Unfractionated cord serum did not inhibit either AS or LDCF, thus ruling out the presence of an excessive amount of chemotactic factor inactivator or an inhibitor in the cord serum.

Humoral inhibitors of chemotaxis, acting directly on cells, have been described in some patients with increased incidence of infections $(19,25,28,32)$. Most of the inhibitors described have been active for neutrophils. Recently, Snyderman (27) detected an inhibitior to monocyte migration in patients who had the Buckley syndrome of increased immunoglobulin E, many allergies, and repeated infections (7). In the experiments described here, both cord serum and normal serum had a significant inhibitory effect on normal monocytes but not on neutrophils. It was interesting that the cord serum was less inhibitory to monocytes than was PNHS, i.e, normal monocytes moved better when suspended in cord serum than when suspended in PNHS. This could be explained if normal serum had had more spontaneous chemotactic activity than cord serum, whereby the former would "deactivate" the cells and thus inhibit their response in a chemotactic analysis $(14,30)$. However, both sera had equal spontaneous chemotactic activity, yet there was a difference in the degree of inhibition, it being much greater for PNHS than for cord serum. This finding suggests that cord serum lacks something that is present in PNHS which is inhibitory to monocytes. It is interesting to speculate what this substance might be: it could be a normal humoral regulator for monocyte chemotaxis, which the newborn infant lacks, and which then would represent a process that is delayed in development.

\section{CONCLUSION}

Simultaneous analysis of monocyte and neutrophil chemotaxis in cord blood revealed a normal to increased monocyte and a decreased neutrophil chemotactic response. In addition, cord 
sera lacked an inhibitor of monocyte chemotaxis which was present in adult serum. No inhibitors of chemotactic factors were detected.

\section{RIEILRENCES ANI) NOTES}

1. Argyris, B. F.: Role of macrophages in immunological maturation. J. Exp. Med. 128: 459 (1968).

2. Ballow, M., Fang, F., Good, R. A., and Day, N. K.: Developmental aspects of complement components in the newborn. Clin. Exp. Immunol., 18: 257 (1974).

3. Bendinelli, M., Senesi, S., and Falcone, G.: Effect of adult perituneal cells on the antibody response of newborn mice to sheep red blood cells. J. Immunol., 106: 1681 (1971).

4. Berenberg, J. L., and Ward, P. A.: Chemotactic factor inactivator in normal human serum. J. Clin. Invest, 52: $1200(1973)$.

5. Böyum, A.: Separation of leukocyles from blood and bone marrow. Scand. J. Clin. Lab. Invest. 21: (Suppl. 97): 31 (1968).

6. Braun, W., and Lasky, L. J.: Antibody formation in newborn mice initiated through adult macrophages. Fed. Proc., 26: 642 (1967).

7. Buckley, R. H., Wray, B. B., and Belmiter, E. Z.: Extreme hyperimmunoglobulinemia $F$ and unduc susceptibility to infection. Pediatrics, 49: 59 (1972).

8. Bullock, J. D., Robertson, A. F., Bodenbender, J. G., Kontras, S. B., and Miller, C. E.: Inflammatory response in the neonate re-examined. Pediatrics, 44: $58(1969)$.

9. Coen, R., Grush, O., and Kauder, E.: Studies of bactericidal activity and metabolism of the leukocyte in full-term neonates. J. Pediat., 75: 400 $(1969)$.

10. Eitzman, D. V., and Smith, R. T.: The non-specific inflammatory cycle in the neonatal infant. Amer. J. Dis. Child., 97: 326 (1959).

11. Gallin, J. I., Clark, R. A., and Frank, M. M.: Kinctic analysis of chemotactic factor generation in human serum via activation of the classical and alternate complement pathways. Clin. Immunol. Immunopathol., 3: 334 (1975).

12. Gitlin, D., Rosen, F. S., and Michael, J. G.: Transient 19-S gamma-globulin deficiency in the newborn infant, and its significance. Pediatrics, 31: 197 $(196,3)$.

13. Kaplow, L. S.: Simplified myeloperoxidase stain using benzidine dihydrochloride. Blood, 26: 215 (1965).

14. Keller, H. U., and Sorkin, E.: Studies on chemotaxis. IV. The influence of serum factors on granulocyte locomotion. Immunology, 10: 409 (1966).

15. Klein, R. B., Rech, K. C., Biberstein, M., and Stichm, E. R.: Defective mononuclear and neutrophil phagecyte chemotaxis in the newborn. Clin. Res. 24: 180A (1976).

16. Kretschmer, R. R., Stewardson, P., Papierniak, C., and Gotoff, S. P.: Chemotaxis of human cord blood monocytes. Pediat. Res., 10: 389 (1976).

17. Kohler, P. F.: Maturation of the human complement system. I. Onset time and sites of fetal $C_{14}, C_{4}, C_{3}$, and $C_{5}$ synthesis. J. Clin. Invest., 52: 671 (1973).

18. Leikin, S., and Oppenheim, J. J.: Differences in transformation of adult and new born lymphocytes stimulated by antigen, antibody and antigen-antibody complexes. Cell. Immunol. I: 468 (1971).

19. Maderazo, E. G., Ward, P. A., and Quintitiani, R.: Defective regulation of chemotaxis in cirrhosis. J. Lab. Clin. Med.. 85: 621 (1975)

20. Mccracken, G. H., and Eichenwald, H. F.: Leukocyte function and the development of opsonic and complement activity in the neonate. Amer. J. Dis. (hild., 121: 120 (1971)

21. Miller, M. E.: Chemotactic function in the human neonate: Humoral and cellular factors. Pediat. Res., 5: 487 (1971).

22. Mtiller, M. F.: Pathology of chemotaxis and random mobility. Sem. Hematol. 12: 59 (1975).

23. Miller, M. E., and Stichm, R. E.: Phagocytic, opsonic and immunoglobulin studies in newborns (medical progress). Calif. Med., 119: 43 (1973).

24. Murczynska, W., Andrejewski, J., and Bogunowica, A.: Role of macrophages in development of immunological maturity in rat. Nature, 227: 721 (1970).

25. Smith, C. W., Hollers, J. C., Dupree, E., Goldman, A. S., and Lord, R. A.: A serum inhibitor of leukotaxis in a child with recurrent infections. J. Lab. Clin. Med., 79: 878 (1972).

26. Snyderman, R., Altman, L. C., Hausman, M. S., and Mergenhagen, S. L.: Human mononuclear leukocyte chemotaxis: $A$ quantitative assay for humoral and cellular chemotactic factors. J. Immunol., 108: 857 (1972).

27. Snyderman, R., and Buckley, R. H.: Defects of monocyte chemotaxis in patients with hyperimmunoglobulinemia $E$ and undue susceptibility to infection. Clin. Res., 23: 25A (1975).

28. Soriano, R. B., South, M. A., Goldman, A. S., and Smith, C. W.: Defect of neutrophil motility in a child with recurrent bacterial infections and disseminated cytomegalovirus infection. J. Pediat., 83: 951 (1973).

29. Stossel, T. P., Alper, C. A., and Rosen, F. S.: Opsonic activity in the newborn: Role of properdin. Pediatrics, 52: 134 (1973).

30. Ward, P. A., and Becker, E. L.: The deactivation of rabbit neutrophils by chemotactic factor and the nature of the available esterase. J. Exp. Med., 127: $693(196,8)$

31. Ward, P. A., and Berenberg. J. L..: Defective regulation of inflammatory mediators in Hodgkin's disease. N. Engl. J. Med., 290: 76 (1974).

32. Ward, P. A., and Schlegel, R. J.: Impaired leukotactic responsiveness in a child with recurrent infections. Lancet, ii: $344(1969)$.

33. We thank Dr. Robert A. Good for helpful criticism. The skilled technical assistance of Mr. Lloyd Augustine, Mrs. Tina Rosen, Miss I:lla Geldwert, and Mrs. Connie Rothermel is greatly appreciated.

34. This research was aided by Public Health Service Research Grants CA-174(1)4 and CA-05826 from the National Institutes of Health: AI-11843 from National Institute of Allergy and Infectious Diseases; and National Foundation-March of Dimes

35. Requests for reprints should be addressed to: S. G. Pahwa, M.D)., Box 368, Memorial Hospital, 1275 York Ave., New York, N. Y. 100)21 (USA)

36. Received for publication August 4, 1976.

37. Accepted for publication October $8,1976$. 